\title{
Yüksek Çözünürlüklü İnsansız Hava Aracı (IHHA) Görüntülerinden Karayolların Tespiti
}

\author{
Abdurahman Yasin YİĞİT ${ }^{1 *}$, Murat UYSAL ${ }^{2}$ \\ ${ }^{1}$ Mersin Üniversitesi, Mühendislik Fakültesi, Harita Mühendisliği Bölümü, Mersin \\ ${ }^{2}$ Afyon Kocatepe Üniversitesi, Mühendislik Fakültesi, Harita Mühendisliği Bölümü, Afyonkarahisar \\ (ORCID: 0000-0002-9407-8022) (ORCID: 0000-0001-5202-4387)
}

\begin{abstract}
$\ddot{\mathbf{O z}}$
Şehir planlaması, meteoroloji, ormancılık, madencilik, tarımsal jeoloji, peyzaj ve haritacılık gibi birçok alanda yüksek çözünürlüklü görüntülerde bulunan bilgilere çeşitli amaçlar için ihtiyaç duyulmaktadır. Yüksek çözünürlüğe sahip görüntülerde yoğun veriler bulunmaktadır ve bu yoğun verilerden istenen detayların otomatik veya yarı otomatik tespiti yapılacak çalışmaya; hız, maliyet ve doğruluk açısından katkı sağlamaktadır. Gelişmiş detay çıkarma yöntemleri sayesinde otomatik detay tespiti daha hızlı ve kolay hale gelmiştir. Bu çalışmada İnsansız Hava Aracı (İHA) ile görünür bölgede (kırmızı-yeşil-mavi bant) elde edilen yüksek çözünürlüklü ham veriler değerlendirilip nesne tabanlı sınıflandırma yaklaşımı ile otomatik olarak karayolu tespiti yapılmıştır. Nesne tabanlı sınıflandırma yöntemiyle; mekânsal, spektral ve bağlamsal bilgi gibi farklı nesne özelliklerine göre sınıflandırılmanın mümkün olduğu gösterilmiştir. Çalışma sonucunda, karayoluna ait ortofoto görüntüsünden nesne tabanlı yaklaşım ile tespit edilen yol ağının yer gerçeği ile ne kadar uyumlu olduğunu belirlemek için iki farklı analiz yapılmıştır. Sınıflandırma kalitesini kontrol etmek için eğitim test alanı (Training Test Area/TTA maskesine dayalı hata matrisi yaklaşımı, hâlihazır harita ile uyumunu araştırmak için ise hata matrisi (Confusionmatrix) ile analiz yapılmıştır. Analiz sonucunda kapa istatistiği 0.7958 , genel doğruluk ve üretici doğruluğu ise sırasıyla $0.7520,0.8158$ hesaplanmıştır.
\end{abstract}

Anahtar kelimeler: İHA, Yol Tespiti, Karayolu Tespiti, Detay Çıkartma, Nesne Tabanlı Sınıflandırma.

\section{Detection of Highways from High-Resolution Unmanned Aerial Vehicle (UAV) Images}

\begin{abstract}
Information contained in high-resolution images in many areas such as urban planning, meteorology, forestry, mining, agriculture, geology, landscaping, and land surveying is needed for various purposes. There are dense data in images with high resolution, and automatic or semi-automatic detection of the details requested from this dense data contributes to the work to be done in terms of speed, cost, and accuracy. Automatic detail detection has become faster and easier thanks to advanced detail extraction methods. In this study, high-resolution raw data obtained in the visible spectrum (red-green-blue band) with Unmanned Aerial Vehicle (UAV) were evaluated and automatic road detection was made with an object-based classification approach. With the object-oriented classification method, it has been shown that it is possible to classify according to different object properties such as spatial, spectral, and contextual information. As a result of the study, two different analyzes were made to determine the compatibility of the road network detected by the object-oriented approach from the orthophoto image of the highway with the ground reality. Error matrix based on TTA mask approach was used to check the classification quality, and analysis was performed with an error matrix (Confusion matrix) to investigate its compatibility with the existing map. As a result of the analysis, the kappa statistic was 0.7958 , the general accuracy and the manufacturer's accuracy were calculated as $0.7520,0.8158$, respectively.
\end{abstract}

Keywords: UAV, Road Detection, Highway Detection, Detail Extraction, Object-Based Classification. 


\section{Giriş}

Düzenli bir kent yapısı oluşturmak için modern otoyollar gibi ulaşım ağlarına ihtiyaç duyulmaktadır [1, 2]. Ülkeler geliştikçe yeni ulaşım ağları yapılmakta ve bu ulaşım ağlarının haritalarının özellikle navigasyon sistemleri için güncellenmesi gerekmektedir. Klasik yöntemler ile haritaların güncellenmesi ve Coğrafi Bilgi Sistemlere (CBS) entegrasyonu zaman ve maliyet yönünden olumsuz etkilenmektedir. Özellikle zamandan tasarruf ve hızlı altyapı hizmetlerinin sunulması açısından yolların tespiti önemli bir adım olarak karşımıza çıkmaktadır. Bu anlamda yoğun veri kümeleri içerisinden yolların çıkarımı ve sinıflandırılması önem arz etmektedir.

Teknolojinin gelişmesi ile veri toplama yöntemleri de gelişme göstermiş ve özellikle görüntü tabanlı veriler, içerisinde daha ayrıntılı bilgiler sunmaya başlamıştır [3-6]. Elde edilen verilerdeki yoğunluk, bu verilerdeki anlamlı olanların çıkarımını zorunlu kılmıştır. Önceleri, istenen detayların çıkarılması operatörler tarafından manuel olarak yapılmaktaydı. Uzun yıllardır manuel olarak yapılan bu çıkarım ve sınıflandırma işlemi gelişen detay çıkarma yöntemleri sayesinde daha hızlı ve kolay hale gelmiştir.

Birçok çalışmada düşük veya orta çözünürlüklü uydu görüntüleri kullanılarak karayolu ağlarının tespiti yapılmıştır. Ancak bu görüntülerdeki yollar genellikle bir veya iki piksel genişliğinde görünür ve bu durumdaki düşük çözünürlüklü görüntülerde bazı yollar ve patika detayları ayırt edilemez. $\mathrm{Bu}$ nedenle yüksek çözünürlüklü görüntülere ihtiyaç duyulmaktadır. Bununla birlikte, bu görüntülerde küçük nesneler gözlemlenebilir hale gelmekte ve dolayısıyla yolun tespit edilmesini etkileyen gürültü (araçlar, gölgeler, işaretler ve yollar boyunca ağaçlar) artmaktadır [7, 8]. Ayrıca yüksek çözünürlüklü görüntülerde yol hatları daha heterojen hale gelmektedir fakat çatılar ve çıplak zeminler gibi spektral olarak benzer bazı nesneler de yol tanıma hatalarına yol açmaktadır [9]. Bu sorunların üstesinden gelmek için yüksek çözünürlüklü görüntülerden yol ağlarını çıkarmak amacıyla bazı algoritmalar önerilmiştir. Örneğin, adaptif yönlü filtreleme [10], Gauss piramidine dayanan bağlamsal bir yöntem [11], ortalama kaydırma filtresinin kullanımı [12] ve morfolojik dönüşüm [13] gibi algoritmalar geliştirilmiştir.

Bacher ve Mayer (2005) yüksek çözünürlüklü çok bantlı uydu görüntülerinden yolların çıkarılması için otomatik bir yaklaşım önermişlerdir [14]. Görüntüleri ilk önce her piksel için üyelik değerlerini içeren "yol sınıfı görüntüsü" olarak sınıflandırmışlar. Sınıflandırma sonuçları ile bir dizi geometrik kısıtlama kullanılarak Steger çizgileri yol hipotezi olarak değerlendirmişlerdir [15]. Wang vd. (2005) çok bantlı (multispektral) görüntülerden yol çıkarma yöntemlerinin, yolların tek tek piksellerin spektral özelliklerine göre diğer zemin özelliklerinden ayrılmasını kapsadığından bahsetmişler [16]. Tapan vd. (2015) çalışmalarında $30 \mathrm{~cm}$ çözünürlüğe sahip kızılötesi sayısal hava fotoğrafları kullanarak ormanlık alanlardaki yolları eğitimli bir sınıflandırma yöntemi ile otomatik olarak belirlemeye çalışmışlardır [17]. Ural vd. (2015) bir metre çözünürlüklü renkli kızı̈ötesi ortofoto ve hava Lidar verileri kullanarak sınıflandırma yapmışlardır. Sınıflandırma işlemi için piksel tabanlı bir yaklaşımın parçası olarak destek vektör makinesi algoritması kullanmışlardır [18]. Becker vd. (2017) insansız hava aracı (IHA) fotogrametrisi verilerinden bina ve yol çıkarımı yapmışlardır ve çalışmalarında makine öğrenmesi ile otomatik detay çıkarma işlemi gerçekleştirmişlerdir [19]. Sabuncu ve Sunar (2017) deprem sonrasında afet bölgesine ait ortofotolardan yararlanarak otomatik bir şekilde nesne tabanlı yöntem kullanarak nesne çıkarımı yapmışlardır [20]. Widyaningrum ve Lindenbergh (2019) çalışmalarında hava LIDAR nokta bulutunu ortofotodan alınan renk bilgileriyle birleştirmişler ve yol ağını çıkarmak için bir metodoloji sunmuşlardır. Çalışmaları, yol ağlarının iskelet tabanlı çıkarımını kapsamaktadır. İlk olarak, zemin noktalarını zemin dışı noktalardan ayırmışlar ardından filtrelenmiş toprak noktalarını Rastgele Orman algoritmasını kullanarak yol ve yol dışı noktalara göre sınıflandırmışlar [21]. Geng vd., (2021) İnsansız Hava Aracı görüntülerinin ultra yüksek uzamsal çözünürlüğe sahip olduğundan bahsetmiş. Çalışmalarında, nesne tabanlı yöntem ile sınıflandırma yapmışlar ve ultra yüksek mekânsal çözünürlüklü multispektral görüntüler ile karşılaştırmalı araştırma yapmışlardır [22]. Zeybek (2021) İHA'dan elde edilen nokta bulutu verilerinden daha fazla bilgi almak için çeşitli analizlere tabi tutuldukları için nokta bulutlarının sınıflandırılması gerektiğine değinmiştir. Nokta bulutlarının yüksek yoğunluğu nedeniyle, veri işleme ve bilgi toplama, nokta bulutlarının sınıflandırılmasını zor bir görev haline getireceğinden ve uzun zaman aldığından bahsetmiş ve bu nedenle sınıflandırma işlemi, değerli bilgiler elde etmek için optimal bir çözüm sağlayacağını aktarmıştır. Zeybek çalışmasında, sınıflandırma işlemi için tercih ettiği rastgele orman makine öğrenme algoritmasında radyometrik özellikler (Kırmızı bant, Yeşil bant ve Mavi bant) ve kovaryans özelliğinden 
(eğrilik, çok değişkenlik, düzlük, doğrusallık, yüzey varyansı, anizotropi ve normalleştirilmiş arazi) türetilen geometrik özellikler uygulamıştır. Ayrıca, İHA tabanlı nokta bulutu üzerinde rastgele orman yönteminin doğruluğunu ve performansını elde etmek için önerilen metodolojinin uygulanabilirliğini test etmek için çalışmasını sunmuştur. Sınıflandırma işleminden sonra, modelden her noktaya atanan bir sınıf, referans veri sınıfı ile karşılaştırılmış ve son olarak sınıflandırmanın genel doğruluğu \% 96 olarak elde edilmiş ve veri setinde Kappa endeksi \% 91'e ulaşmıştır [23].

Uzaktan algılanan verilerden bilgi elde etmek için piksel tabanlı yaklaşımlar uygulanırsa yalnızca spektral bilgi kullanılır. Bu nedenle, piksel tabanlı yaklaşımlar yüksek çözünürlüklü görüntü sınıflandırmasını karşılayamaz. $\mathrm{Bu}$ durum zengin bilgi içeriğine sahip yüksek çözünürlüklü görüntülerde uygulanan piksel tabanlı sınıflandırma yönteminde bina, yol, park vb. kesin sınırlar içeren kentsel alanlardan hassas veri çıkarımı oldukça güçleştirir. $\mathrm{Bu}$ eksiklik mevcut bilgi işlem teknolojilerine bağlı olarak gelişmiş görüntü analiz ve sınıflandırma yaklaşımlarını da beraberinde getirmiştir. Dolayısıyla günümüz görüntü işleme ve uzaktan algılama teknolojilerinde, nesne tabanlı sinıflandırma yaklaşımları yoğunlukla kullanılmaya başlanmıştır $[15,23-26]$. Nesne tabanlı sınıflandırma yaklaşımına göre bir nesne; benzer spektral ve mekânsal özelliklere sahip bir piksel grubu olarak tanımlanır. Bu yaklaşımda, nesneleri temsil eden segmentler; şekil, doku, komşuluk ilişkisi, morfolojik ilişkiler, alan, yükseklik değeri, mesafe, geometrik şekil, standart sapma, yoğunluk vb. değerleri kullanılarak analiz edilir ve hedef sınıflara atanır. Bu bilgilerin çoğu nesne tabanlı sinıflandırma yöntemine özgüdür, piksel tabanlı sınıflandırma yönteminde kullanılamazlar. Nesneye ait farklı özellikler kullanılarak daha doğru sınıflandırma sonuçları elde edilir [27].

Bu çalışmada İHA'dan elde edilen görüntülerden oluşturulan yüksek çözünürlüğe sahip ortofoto kullanılarak nesne tabanlı sınıflandırma yöntemi ile kentsel alanlardaki yolların ve benzeri hatların belirlenen kural ve işlemler ile otomatik çıkarımı amaçlanmıştır. Alçak irtifa İHA'lar, son yıllarda, kullanıcının ilgi alanlarına göre çok açılı ve çok yüksek çözünürlüklü uzaktan algılama verilerini elde edebilen ve iniş yerlerinin veya bulut örtüsünün koşullarından daha az kısıtlanan rakipsiz özelliklere sahip yeni bir düşük maliyetli uzaktan algılama veri kaynağı olmuştur. Bu esneklik ve verimlilik nedeniyle, uydu verilerine iyi bir tamamlayıcı olan İHA'lardan elde edilen görüntü verilerinden yol tespitinde kullanılabilirliği bu çalışmada araştırılmıştır. Bu bağlamda çalışmanın amacı, karayolu hatlarının tespitinde İHA'dan elde edilen RGB görüntü verilerinin uygulanabilirliğini test etmektir.

İHA ile elde edilen yüksek çözünürlüklü görüntülerden bilgi almak için bir nesnenin ve çevresinin mekânsal ve spektral bilgilerin kullanılması gerekir. Çalı̧̧mada; segmentasyon ve sınıflandırma için farklı parametrelerin uygulanması, kompozit ve orijinal bantların kombine kullanımı, farklı ölçek seviyelerinin seçilmesi ve kural setlerin seçiminin detay çıkartımı üzerindeki etkisi araştırılmıştır. Nesne tabanlı sınıflandırma yöntemi ile tespiti yapılan yol hatlarının yer gerçeği ile ne kadar uyumlu olduğunu belirlemek için doğruluk analizi yapılmıştır. Sınıflandırma kalitesini kontrol etmek için TTA maskesine dayalı hata matrisi yaklaşımı, halihazır harita ile uyumunu araştırmak için ise hata matrisi (Confusion matrix) ile analiz yapılmıştır. Analiz sonucunda, seçilen test alanlarının referans değerleri ile sınıflandırma sonucu karşılaştırılarak hata matrisi üretilmiş ve kapa istatistiği, üretici ve kullanıcı doğruluğu, hassasiyet, duyarlılık, $F 1$ Puanı ve özgünlük sırasıyla hesaplanmıştır.

\section{Materyal ve Metot}

Bu çalışmada yüksek çözünürlüklü görüntülerden üretilen ortofotolardan nesne tabanlı sınıflandırma yöntemi ile karayolların tespiti yapılmıştır. Bu kısım Çalışma alanı, veri temini, İHA verilerinin fotogrametrik süreci, Nesne tabanlı sınıflandırma ve doğruluk analizi kısımlarından oluşmaktadır.

\section{1. Çalışma Alanı}

Çalışma alanı olarak Şekil 1'de gösterilen Yozgat-Sivas hattında bulunan karayolu seçilmiştir. 


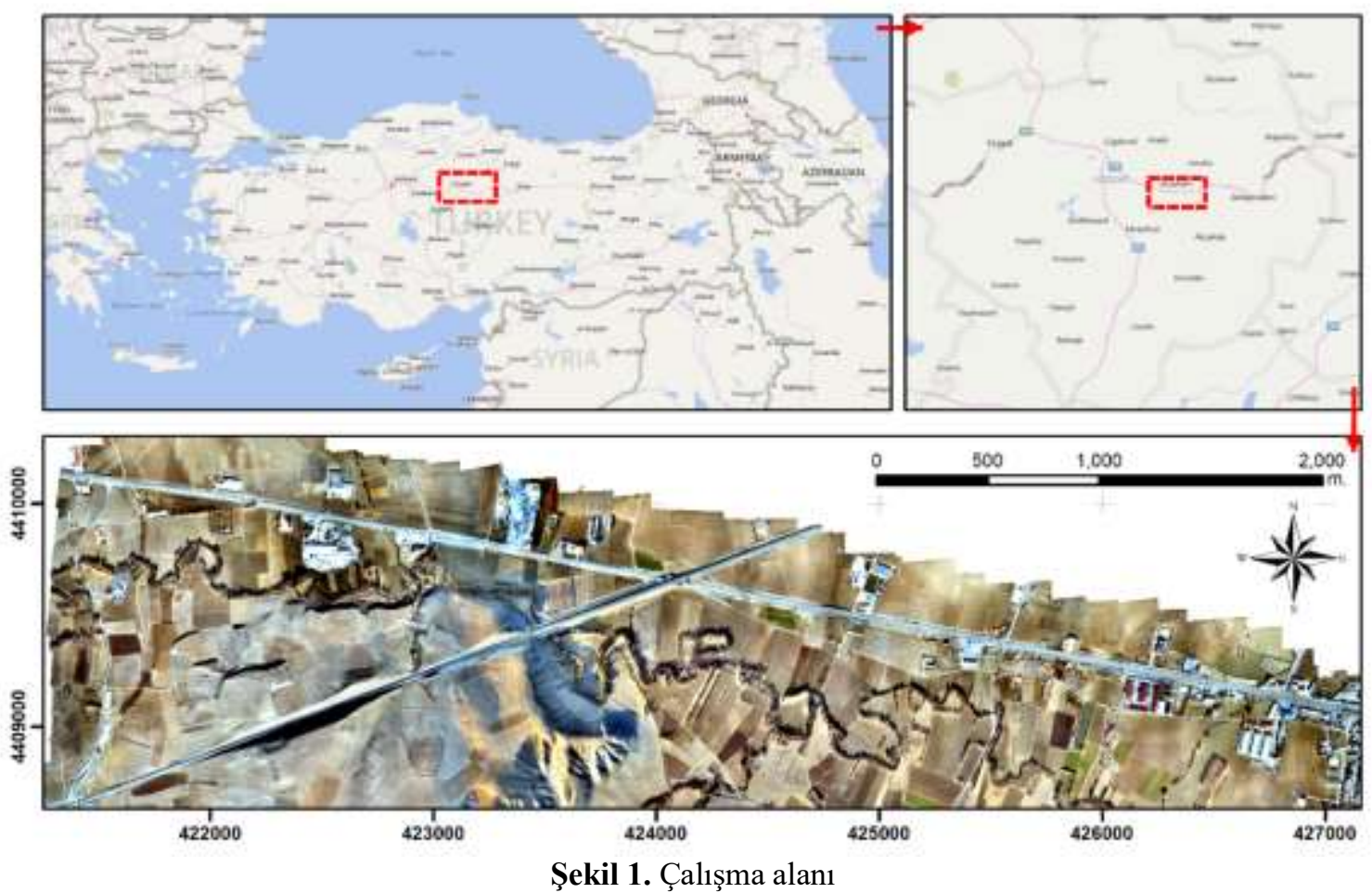

\subsection{Veri Temini}

Çalışmada ilk olarak Şekil 2'de verilen İHA ile yaklaşık 70 hektarlık bir alanda 215 metre yükseklikten RGB bantlara sahip S.O.D.A kamera ile görüntüler toplanmıştır. Toplam 312 fotoğraf çekilmiş olup tamamı kullanılmıştır. Araziye 16 adet yer kontrol noktası (YKN) tesis edilmiş olup YKN'ler Küresel Konum Belirleme Sistemi (Global Navigation Satellite System/GNSS) ile çalışan bir hassas ölçüm cihazı ile birer saat arayla 30 epok ( 1 epok $=1 \mathrm{sn})$ olacak şekilde iki kez tekrarlı olarak ölçülmüştür. Çalışmada kullanılan İHA ve kameranın teknik özellikleri Tablo 1'de verilmiştir.

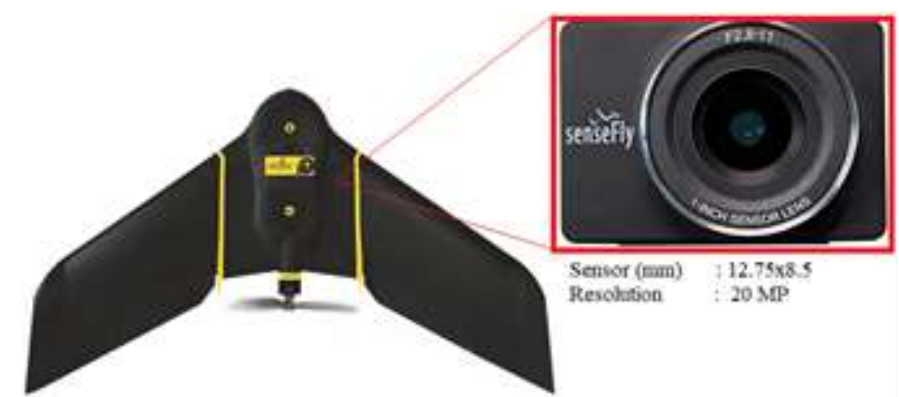

Şekil 2. ebee sensefly plus sabit kanatlı İHA ve S.O.D.A kamera

Tablo 1. Ebee sensefly plus sabit kanatlı İHA ve S.O.D.A. kamera teknik özellikler

\begin{tabular}{ll}
\hline Özellik & Değer \\
\hline Ağırlık & $1100 \mathrm{~g}$ \\
Çapraz Boyut & $1100 \mathrm{~mm}$ \\
Seyir hızı & $40-110 \mathrm{~m} / \mathrm{s}$ \\
Maksimum Uçuş Süresi & Yaklaşı 50 dakika \\
PPK/RTK & Var \\
Radio link mesafesi & $3 \mathrm{~km}$ etkili \\
Uydu Konumlandırma Sistemleri & Var \\
Kamera modeli & Sensefly S.O.D.A \\
Sensör tipi & R-G-B $(20 \mathrm{mp})$ \\
Sensör boyutu & 1 -inch \\
Çözünürlük & $5472 \times 3648$ \\
Odak uzaklığ 1 & $10.6 \mathrm{~mm}$ \\
\hline
\end{tabular}




\section{3. İHA Verilerinin Fotogrametrik Süreci}

İHA ile çekilen görüntüler, fotogrametrik değerleme yazılımı ile dengelenmiştir. Dengeleme sonunda araziden ölçümü yapılan YKN'ler kullanılarak arazi koordinatlarına dönüştürülmüştür. Daha sonra çalışma alanının ortofotosu üretilmiştir.

\subsection{Nesne Tabanlı Sınıflandırma}

Nesne tabanlı görüntü analiz yöntemi; görüntüdeki şekil, renk, doku vb. ayırt edilebilir özelliklere göre nesneleri yakalayan bir sistem sağlar. Bu yöntem; görüntüdeki binalar, ağaçlar, yollar ve araçlar gibi çeşitli nesneleri ayırt etme imkânı sağlar. Nesne tabanlı sınıflandırma yöntemi, segmentasyon ve sınıflandırma aşamalarını içerir. Segmentasyon süreci, görüntü üzerindeki hedef sınıfların aynı segmentte toplanmasına izin verirken ikinci aşama ise nesnelerin sınıflandırılmasını gerektirir [28]. Çalışmada nesneye dayalı bir sınıflandırma yaklaşımı gerçekleştirmek için Definiens eCognition Developer $[44,45]$ yazılımı kullanılmıştır.

Nesne tabanlı sinıflandırmada en önemli ve ilk adım segmentasyondur. Segmentasyon, benzer spektral özelliklere sahip pikselleri gruplama ve görüntü nesneleri oluşturma işlemidir. Segmentasyonun amac1, görüntüyü farklı alt bölümlere ayırmak ve görüntüden anlamlı nesneler oluşturmaktır [29]. Definiens yazılımında segmentasyon işleminde ölçek, şekil yoğunluk ve yumuşaklık parametreleri vardır [4]. Mümkün mertebe gerçeğe en yakın değerde girilmesi gereken parametreler arasında en önemlisi ölçek parametresidir. Kullanıcılar, farklı ölçeklerdeki nesneleri belirlemek için şekil ve yoğunluk faktörleri için 0 ile 1 arasında değişen ağırlıklar uygulayabilir. Bu iki parametre nesnelerin homojenliğini kontrol eder. Şekil faktörü, nesnelerin şekline karşı spektral homojenliği ayarlarken, yoğunluk faktörü ve pürüzsüzlüğ̈ dengeleyen yumuşaklık faktörü, nesne şeklini pürüzsüz sinırlar ve kompakt kenarlar arasında belirler. Ayrıca, yumuşaklık ve yoğunluk toplamı bire eşit olmalıdır. Yoğunluk veya yumuşaklık yalnızca şekil faktörü sıfırdan büyük olduğunda etkilidir (Benz et al. 2004). Kullanıcının gerekli ayrıntı düzeyiyle eşleşen nesne boyutunu kontrol eden ölçek parametresi, görüntü segmentasyonunun en önemli parametresi olarak kabul edilebilir. Çalışmada segmentasyon yöntemi olarak Çoklu çözünürlüklü segmentasyon yöntemi kullanılmıştır. Çoklu çözünürlüklü segmentasyon algoritmasında görüntü nesneleri, belirli bir çözünürlük için ortalama heterojenliğe (Denklem 1) dayalı olarak küçük parçalara bölünür.

Heterojenlik kriteri (f) belirli bir eşiğin altında olmalıdır. Ağırlık parametreleri Wcolor ve Wshape heterojenliği belirler.

$$
\begin{aligned}
& f=W_{\text {color }} \cdot \Delta \mathrm{h}_{\text {color }}+W_{\text {shape }} \cdot \Delta \mathrm{h}_{\text {shape }} \\
& W_{\text {color }} \in[0,1], W_{\text {shape }}+W_{\text {color }}=1 \\
& \Delta \mathrm{h}_{\text {color }}=\Sigma_{c} \mathrm{~W}_{c} \cdot\left(n_{\text {merge }} \cdot \sigma_{c, \text { merge }}-\left(n_{\text {obj-1 }} \cdot \sigma_{c, o b j-1}+n_{\text {obj-2 }} \cdot \sigma_{c, o b j-2}\right)\right)
\end{aligned}
$$

$\mathrm{Bu}$ denklemlerde:

$W_{c}$ : c bandında ağırlık

$n_{\text {merge }}$ : birleştirilmiş nesnedeki toplam piksel sayısı

$n_{o b j-1}$ : ilk nesnedeki toplam piksel sayıs1

$n_{o b j-2}$ : ikinci nesnedeki toplam piksel sayıs1

$\sigma_{c}$ : c bandındaki standart sapma

$o b j-1$ : birleştirmeden önceki nesneler olarak tanımlanır.

$$
\begin{aligned}
& \Delta \mathrm{h}_{\text {shape }}=W_{\text {compt }} \cdot \Delta \mathrm{h}_{\text {compt }}+W_{\text {smooth }} \cdot \Delta \mathrm{h}_{\text {smooth }} \\
& \Delta \mathrm{h}_{\text {smooth }}=\mathrm{n}_{\text {merge }} \cdot \frac{l_{\text {merge }}}{b_{\text {merge }}}-\left(n_{o b j-1} \cdot \frac{l_{o b j-1}}{b_{o b j-1}}+n_{o b j-2} \cdot \frac{l_{o b j-2}}{b_{o b j-2}}\right)
\end{aligned}
$$


$\Delta \mathrm{h}_{\mathrm{compt}}=\mathrm{n}_{\text {merge }} \cdot \frac{l_{\text {merge }}}{\sqrt{n}_{\text {merge }}}-\left(n_{o b j-1} \cdot \frac{l_{o b j-1}}{\sqrt{n_{o b j-1}}}+n_{o b j-2} \cdot \frac{l_{o b j-2}}{\sqrt{n_{o b j-2}}}\right)$

Yukarıdaki denklemlerde,

1: nesnenin çevresi,

b: nesne hattını çevreleyen uzunluk olarak tanımlanır.

İyi bir görüntü segmentasyonu için $w c$, wcolor, wshape, wsmooth, wcompt parametreleri gereklidir. Optimizasyon sürecini durdurmak için ölçek parametresi gereklidir. Heterojenlikteki fark (f), iki bitişik nesneyi birleştirmeden önce hesaplanır. Artış, ölçek parametresi tarafından belirlenen eşik değeri t $(\mathrm{t}=\Psi$ (ölçek parametresi)) aştığında, nesne birleştirme işlemi durdurulur ve bölümleme tamamlanır. Daha büyük bir ölçek parametresinin belirtilmesi, daha fazla nesnenin birleşimine yol açarak daha büyük nesnelerle sonuçlanır.

Nesne bazlı sınıflandırma işleminde segmentler oluşturulduktan sonra çeşitli bant kombinasyonları oluşturulur ve objelerin karşılık gelen gri renk aralığından istenen detaylar elde edilir. $\mathrm{Bu}$ işlemin amacı, kullanılan bant kombinasyonlarının özelliklerini ve görüntü detaylarını ortaya çıkarmaktır. $\mathrm{Bu}$ amaçla, literatürde birkaç grup kombinasyonu rapor edilmiştir. Çalışmada görünür dalga boylarındaki görüntüler kullanıldığından, bu bantlarla ilişkili indeksler kullanılmıştır. Literatürde en sık kullanılan indekslerden bazıları Tablo 2'de sunulmuştur.

Tablo 2. KYB (Kırmızı-Yeșil-Mavi/Red-Green-Blue) bant indeksleri

\begin{tabular}{|c|c|c|c|}
\hline İsim & Kisaltma & Formül & Kaynak \\
\hline $\begin{array}{l}\text { Ortak Bantlar Oranı } \\
\text { (Common Band Ratio) }\end{array}$ & $\begin{array}{l}\mathrm{OBO} \\
(\mathrm{CBR})\end{array}$ & $(K+Y+M) / 3$ & [30] \\
\hline $\begin{array}{c}\text { Kırmızı Yeşil Bant Farkı } \\
\text { (Red-Green Band Difference) }\end{array}$ & K-Y (R-G) & $K-Y$ & [30] \\
\hline $\begin{array}{l}\text { Aşırı Yeşil İndeks } \\
\text { (Excess green index) }\end{array}$ & AYI (EGI) & $(2 x Y)-M-K$ & [31] \\
\hline $\begin{array}{l}\text { Yeşil Yaprak alan İndeksi } \\
\text { (Green Leaf area index) }\end{array}$ & YYİ (GLI) & $((2 x Y)-M-K) /((2 x Y)+M+K)$ & [31] \\
\hline $\begin{array}{c}\text { Üçgen Yeşillik İndeksi } \\
\text { (The Triangular Greenness Index) }\end{array}$ & UYİ (TGI) & $Y-(0.39 R-0.69 B)$ & [31] \\
\hline $\begin{array}{c}\text { Yeşil Bant Oranı } \\
\text { (Green Ratio Index) }\end{array}$ & YBO (GRI) & $Y /(M+Y+K)$ & [32] \\
\hline $\begin{array}{l}\text { Mavi Bant Oranı } \\
\text { (Blue Ratio Index) }\end{array}$ & MBO (BRI) & $M /(M+Y+K)$ & [30] \\
\hline $\begin{array}{l}\text { Kırmızı Bant Oranı } \\
\text { (Red Ratio Index) }\end{array}$ & KBO (RRI) & $K /(M+Y+K)$ & [30] \\
\hline $\begin{array}{c}\text { Yeşil-Kırmızı Vejetasyon İndeksi } \\
\text { (The Synthetic NDVI) (Green Red } \\
\text { Vegetation Index) }\end{array}$ & $\begin{array}{l}\text { YKVI } \\
\text { (sNDVI } \\
\text { GRVI) }\end{array}$ & $(Y-K) /(Y+K)$ & [33] \\
\hline $\begin{array}{c}\text { Ayarlı Bitki Örtüsü İndeksi } \\
\text { Vegetation Adjusted Reflectance Index }\end{array}$ & $\begin{array}{c}\text { ABİ } \\
(\mathrm{VARI})\end{array}$ & $(Y-K) /(M+Y+K)$ & [34] \\
\hline $\begin{array}{l}\text { Aşırı kırmızı bitki örtüsü indeksi } \\
\text { Excess red vegetation İndex }\end{array}$ & $\begin{array}{c}\text { AKBI } \\
(\mathrm{ERVI})\end{array}$ & $(1.4 x K)-Y$ & [35] \\
\hline
\end{tabular}

Görüntüler anlamlı segmentlere ayrıldıktan sonra, her bir bölümün özellikleri test edilmeli ve her bir görüntü bandı ve görüntü bölümündeki her özelliğin tepkileri analiz edilmelidir. Analiz, ilişkili sınıfın ayrımını yakalayan özelliğe dayalı olarak sınıfı en iyi temsil edebilecek sınır değerlerinin belirlenmesine yol açmaktadır. Böylelikle sınıflandırma, ilgili üyelik fonksiyonunda belirlenen limitler 
ile devam etmekte ve gerçek dünya koşullarını temsil eden en iyi sınıflandırma elde edilinceye kadar bu limitler araştırılmalıdır.

Çalışmada sadece yolların tespiti yapıldığı için yol nesneleri yol sınıfına, yol dışındaki nesneler ise yol olmayan olarak sınıflandırılmıştır. Yol sınıfları belirlenirken yol dışı nesnelerin kaldırılması için maskeleme yapılmıştır. Böylece, her bir nesnenin değerleri test edilmiş ve nesneler yol dişı sınıfa atanmıştır. Segmentler sınıflara atandıktan sonra, sıkıştııılmış segment kenarlıkları ve şekilleri düzeltilmiştir.

Çalışmanın iş akış şeması Şekil 3'te gösterilmiştir.

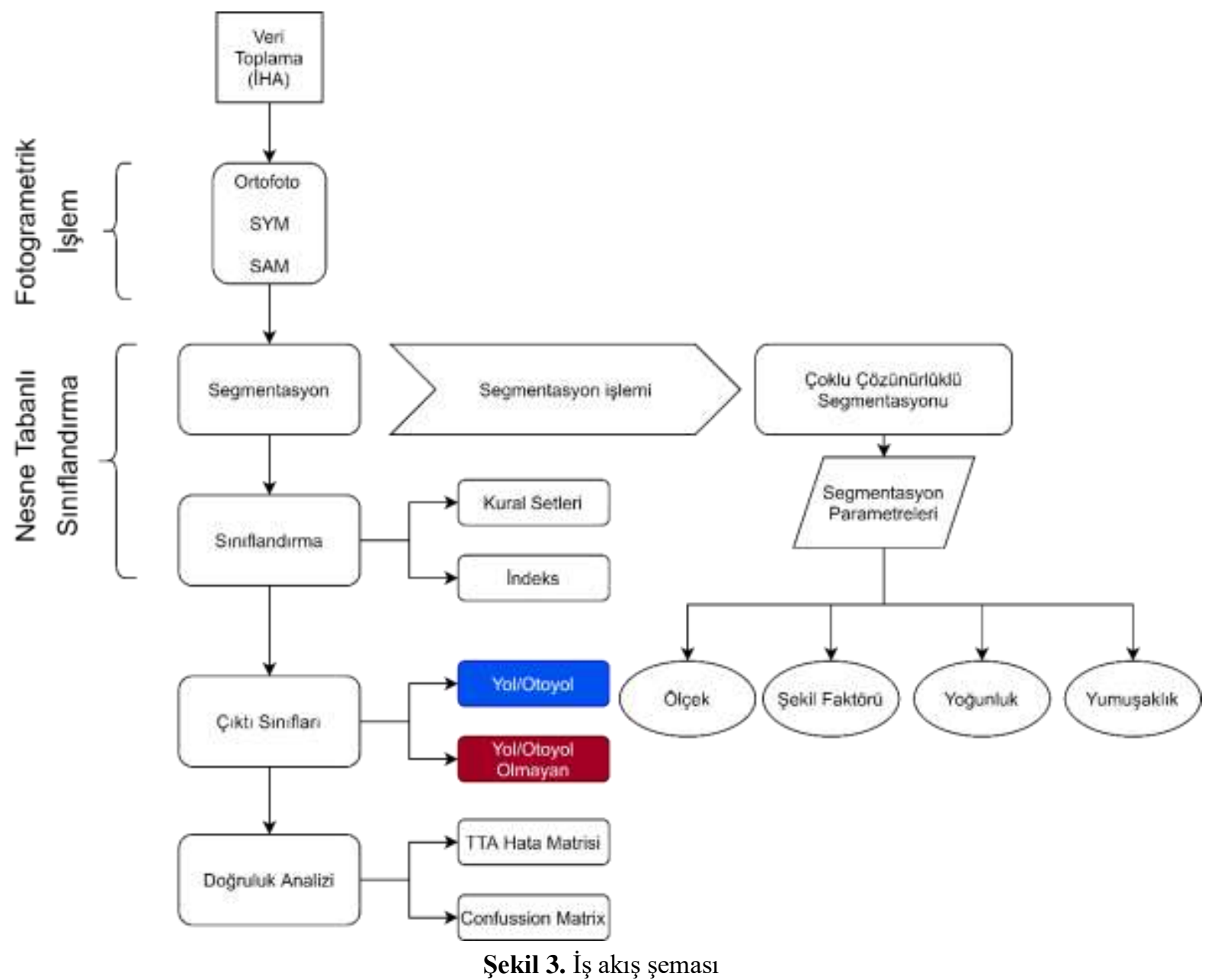

\subsection{Doğruluk analizi}

Sınıflandırmadan sonra, sınıfların gerçek alanla uyumluluğunu belirlemek için doğruluk analizi yapılmalıdır. Doğruluk analizi, sınıflandırmanın doğruluğunu ve güvenilirliğini ölçmek için son adımdır. Doğruluk analizi için bir hata matrisi geliştirilmiş, kullanıcı ve üretici doğrulukları ve kappa katsayısı analiz edilmiştir. Daha sonra bu noktaların konumlarının doğruluğunu test etmek için CBS yazılımında rastgele noktalar atanmıştır. Rastgele atanacak olan noktaların sayısını belirlemek için oluşan segmentlere göre örneklem belirlenmiş ve örneklem uzayına göre nokta sayısı belirlenmiştir.

Sınıflandırma sonuçlarının validasyonu için sınıflandırma doğruluğu elde edilen sonuçları anlamak ve sonuçların karar verici mekanizmalarca kullanılabilmesi için doğru tahminler gereklidir. En yaygın doğruluk tahmin parametreleri genel doğruluk, üretici doğruluğu, kullanıcı doğruluğu ve Kappa katsayısıdır [36, 37].

Genel doğruluk, doğru olarak sınıflandırılan toplam piksel veya görüntü nesnesi sayısının referans verilerindeki toplam öğe sayısına bölünmesiyle hesaplanır (Denklem 7). 
General doğruluk $=\frac{\sum_{k=1}^{n} N_{k, k}}{\sum_{j=1}^{n}\left(\sum_{i=1}^{n} N_{i, j}\right)}$

şeklinde olur.

Her bir kategorinin doğruluğu, bu kategoride doğru sınıflandırılmış nesnelerin sayısının karşılık gelen satır veya sütundaki eleman sayısından herhangi birine bölünmesiyle hesaplanır.

Üretici doğruluğu (Denklem 8), her kategoride doğru sınıflandırılmış piksel veya nesne sayısının, o kategori için seçilen toplam gerçek örnekleme türü sayısına (sütun toplamı) bölünmesiyle hesaplanır.

$P A N_{i}=\frac{N_{i, i}}{\sum_{j=1}^{n} N_{i, j}}$

Üretici doğruluğu denklem 8'de gösteriliği gibi hesaplanır. Burada, $P A N_{i}$ (PAN= normal sınıflandırma için üretici doğrulu), i. kategorinin üretici doğruluğu, n sınıflandırma kategori sayısını oluşturmaktadır. Üretici doğruluğu, görüntüdeki gerçek örtü tipinin ilgili sınıfa dâhil edilme başarısını gösterir.

Kullanıcı doğruluğu (Denklem 9), her kategoride doğru olarak sınıflandırılan piksel veya nesne sayısının, o kategoride sınıflandırılan toplam piksel veya nesnelerin (toplam satır) sayısına bölünmesiyle elde edilir. Bu doğruluk kriteri, ekleme hatasının bir ölçüsüdür ve belirli bir kategoride sınıflandırılan piksel veya nesnenin, gerçek dünya toprak örtüsü tipindeki kategoriyi temsil etme olasıllı̆ını ifade eder. Kullanıc1 doğruluğu,

$U A N_{j}=\frac{N_{j, j}}{\sum_{J=1}^{n} N_{j, i}}$

ile hesaplanır. Burada, $\operatorname{UAN}_{j}$ (UAN= normal sınıflandırma için kullanıcı doğruluğu) kategorinin kullanıcı doğruluğudur.

Doğruluk analizi, sınıflandırma sonucunda elde edilen verilerin referans olarak kabul edilmiş olan veriler ile istatistiksel olarak karşılaştırılmasını esas alan bir doğruluk kontrol etme yöntemidir. Yapılan bu istatistiksel analizler sonucunda elde edilen hata matrisi ile sınıflandırma sonucunun sağlıklı olup olmadığı anlaşılmaktadır. Hata matrisi, 0 ile 1 arasında değişiklik gösteren kappa katsayısı (Denklem 10) ile istatistiksel olarak analiz edilir [38].

k değeri kappa katsayısını göstermek üzere,

$k=\frac{P_{0}-P_{h}}{1-P_{h}}$

ile hesaplanır.

P0 değeri hata matrisinin köşegenlerindeki elemanların toplamının, her satır veya sütunundaki elemanlarının toplamına oranlanması ile elde edilir.

$P_{h}=\sum P_{a}(i) P(i)$

$\mathrm{P} \alpha$ değeri, ayrı ayrı her bir sütunun toplamlarının, tüm sütunların toplamına bölünmesi ile bulunmaktadır.

$\mathrm{P}$ değeri ise, ayrı ayrı her bir satırın toplamlarının, tüm satırların toplamına bölünmesi ile bulunmaktadır [39].

Hata matrisi oluşturularak yapılan doğruluk analizinden sonra coğrafi bilgi sistemleri yazılımında yapılan nokta konum doğrulukları ile çalışmanın doğruluk (Denklem 12), hassasiyet (Denklem 13), duyarlılık (Denklem 14), F1Puanı (Denklem 15) ve özgünlük (Denklem 16) hesaplanmıştır. 
Bunun için örneklem büyüklüğ̈̈ incelenmiş ve gerekli olan örneklem sayısı kadar rastgele nokta atılmıştır (10112 tane). Rastgele atılan aynı noktalar, tespit edilen yolların olduğu harita üzerine de atılmıştır. İlk olarak bu işlem içinde örneklem tespit edilmiştir. Örneklem sayısı belirlendikten sonra bu sayı kadar rastgele nokta atılmıştır. Atılan bu noktaların, referans verisindeki konumlarının tespit edilen yolların oluşturduğu vektör haritadaki durumu incelenmiştir. Bunun için;

Gerçek pozitif (GP): yol noktaları doğru sınıfa (Evet)

Gerçek negatif (GN): yol olmayan noktalar yol olmayan sınıfa (Hayır)

Yanlış pozitif (YP): yol olmayan noktalar yol sınıfa (Evet)

Yanlış negatif (YN): yol olan noktalar yol olmayan sınıfa (Hayır)

$$
\begin{aligned}
& \text { Doğruluk }=\frac{(G P+G N)}{(G P+Y P+Y N+G N)} \\
& \text { Hassaiyet }=\frac{(G P)}{(Y P+Y P)} \\
& \text { Duyarlılık }=\frac{(G P)}{(G P+Y N)} \\
& F_{1} \text { Puanı }=2 * \frac{(\text { Hassasiyet } * \text { Duyarllllk })}{(\text { Hassasiyet }+ \text { Duyarllllk })} \\
& \text { Özgünlük }=\frac{(G N)}{(G N+Y P)}
\end{aligned}
$$

\section{Bulgular ve Tartışma}

Nesne tabanlı sınıflandırma yöntemi ile detay tespiti çalışmaları çoğunlukla uydu görüntüleri ile yapılmaktaydı. Düşük ve orta çözünürlüklü uydu görüntüleri zayıf mekânsal çözünürlükle sınırlıdır. Bu nedenle, İHA'lar küçük alanlar için yüksek mekânsal çözünürlüklü görüntüler toplamada iyi bir alternatif olmuştur. Son zamanlarda İHA'lar ile yüksek çözünürlüklü ortofotoların üretilmesi sonucunda bu görüntülerden obje tespiti çalışmalarına ağırlık verilmeye başlanmıştır. İHA görüntülerinden üretilen yüksek çözünürlüklü ortofotolardan nesne tabanlı sınıflandırma yöntemi ile yol detaylarının tespiti amaçlanmıştır.

İHA ile çekilen görüntülerin fotogrametrik olarak dengeleme işlemi Pix4D yazılımında yapılmıştır. Dengeleme sonucunda çalışma bölgelerin ortofotoları üretilmiş (Şekil 4) ve üretilen ortofotoların yer örneklem aralığı (YÖA) 6,1 cm çözünürlüğe sahiptir.

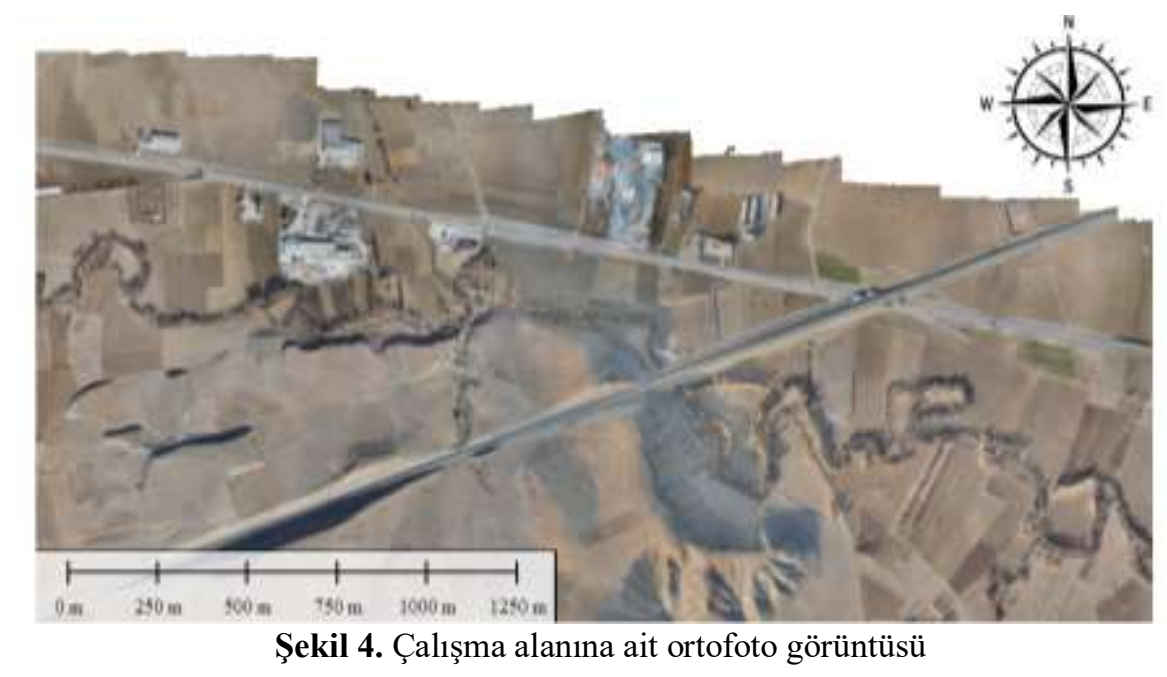


Yüksek çözünürlüklü İHA görüntülerinden üretilen ortofotolardan nesne tabanlı sınıflandırma metodu uygulanmasında en önemli ve ilk aşama şüphesiz segmentasyon aşamasıdır. Segmentasyonu etkileyen parametrelerden (şekil-kompaktlık-ölçek) en önemlisi ölçek parametresidir.

İlk olarak ölçek parametresi sabit tutularak şekil ve kompaktlık parametreleri deneme yanılma yöntemiyle seçilmiştir. Bu sonuçların analiz edilmesiyle, şekil değişikliği parametresinin kompaktlık indeksine kıyasla segmentasyon sonuçlarının kalitesine daha duyarlı olduğu ve daha küçük bir şekil parametresinin ayarlanmasının ideal segmentasyon sonuçlarının elde edilmesinde daha kolay olduğu ortaya konulmuştur.

Şekil parametresi, daha az ağırlık şekli vermek ve görüntü segmentasyonu için spektral olarak daha homojen piksellere daha fazla dikkat vermek üzere 0.3 'e ayarlanmıştır. Kompaktlık parametresi, nesnelerin kompaktlığını ve pürüzsüzlüğünü dengelemek için $0,7^{\prime} \mathrm{e}$ ayarlanmıştır. Farklı ölçek seviyelerini ve parametre değerlerini test ettikten ve kalitatif olarak değerlendirdikten sonra, 20 'den 150'ye kadar ölçek seviyeleri denenmiş ve en uygun ölçek seviyesi 150 olarak uygun görülmüştür (Şekil $5)$.

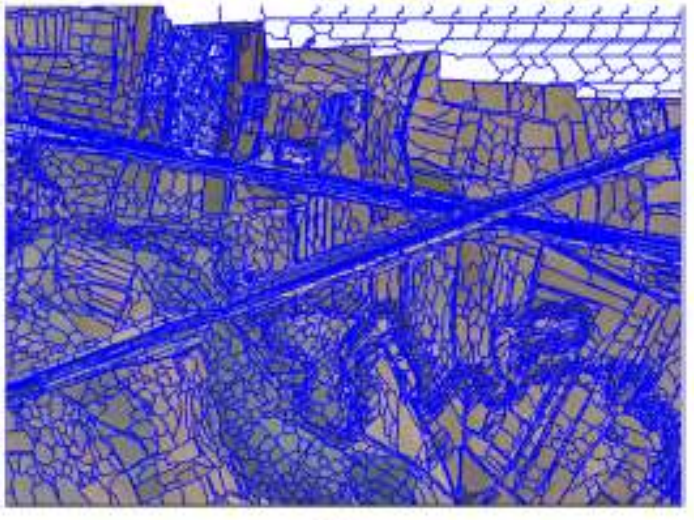

(A)

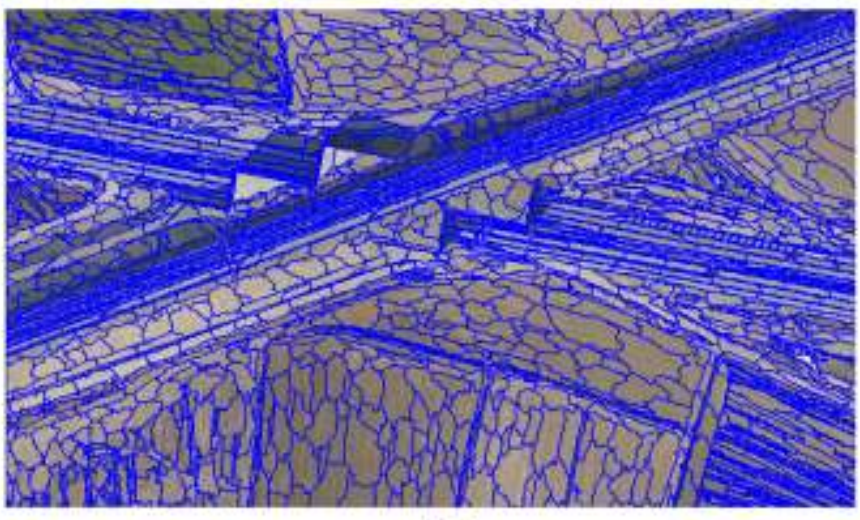

(B)

Şekil 5. Segmentasyon (A: ölçek 100 - B: Ölçek 150)

Ölçek işlevindeki farklı sayılar için uygulanarak farklı nesne boyutu düzeyleri belirlenebilir. Daha yüksek ölçek (örneğin, 100) daha büyük homojen nesneler üretir (daha küçük bir kartografik veya haritalama ölçeğine benzer), daha az ölçek (örneğin, 10) daha küçük nesnelere (daha büyük ölçek) yol açar. Ölçek parametresinde kullanılan daha büyük bir sayı, segmentasyon prosedüründe daha düşük bir seviye olarak kabul edilir. Ölçek düzeyine ilişkin karar, hedefe ulaşmak için gereken nesnenin boyutuna bağlıdır.

Yapılan bir segmentasyon işleminin optimum düzeyde olduğunu değerlendiren en iyi ve tecrübeli kaynak şüphesiz insan gözüdür. Munoz vd. (2003), bölgeyi ve sınır bilgilerini bütünleştiren çeşitli segmentasyon yaklaşımlarının avantaj ve dezavantajlarına dikkat çekmiş ve bilgisayar görüşünün ve uygulamalarının ilerlemesi için çok önemli olan mükemmel bir segmentasyon algoritmasının olmadığını bildirmiştir [40].

Belgiu and Dragut (2014) jeo-uzamsal verilerdeki ölçek dönüşümlerini tespit etmek için yerel varyans potansiyeline dayanan yinelemeli bölümleme için ESP2 aracını kullanmışlardır [41]. Bu araç nesne tabanlı sınıflandırmada ölçek parametresi seçiminde iyi bir uygulanabilirliğe sahip olduğu [42] belirtilse de yalnızca yarı otomatik bir ölçek parametresi seçim aracı olmaktadır. Bu araç ile lokal varyans eğrisi çok yumuşak olmaktadır ve segmentasyonun ilk parametreleri mantıksız bir şekilde ayarlanacağı için bükülme noktası belirgin olmayacaktır. Bu sebeple segmentasyon sonucu (nicel olarak çok iyi hesaplanmış olsa bile) insan gözünü yeterince memnun etmediği sürece tam olarak anlamlı sayılamaz. Burada oluşan görüntü segmentlerinin görüntü nesneleri ile benzer şekilde ve boyutta olması önemlidir. Ancak burada en az sınır yumuşatması ile görüntü nesnelerinin üretilmesi için karışık ve dokulaşmış verideki spektral homojenliğin ortaya çıkarılması oldukça zordur.

$\mathrm{Bu}$ ölçek seviyelerinin sınıflandırma için uygun olup olmadığını değerlendirmek için, ayrımcı analiz yapmak üzere 25, 50, 100, 150 ve 200 ölçeklerinde sınıf başına 10 farklı nesne seçilmiştir. Segmentlere ayrılan nesneleri, seçilen ölçek düzeylerinde görsel olarak kontrol edilmiştir ve aynı 
sınıflardan önemli ölçüde farklı nesneler seçilmiştir. Seçilen sınıfların hedef nesneleri orijinal arazi örtüsü kategorileriyle aynı olmasına özen gösterilmiştir. Her bir spektral banttaki nesnelerin ortalama değerlerini, etkin bir şekilde ayrılabilir olup olmadıklarını değerlendirmek için öngörücü değişkenlerin doğrusal kombinasyonlarına dayanan bir diskriminant fonksiyon oluşturmak için kullanılmıştır. Her detayın kendisine özgü bir ölçek parametresi vardır. Bundan dolayı tespit edilmesi istenilen nesneye göre segmentlerin seçilmesi önemlidir. Örneğin bina detayının çıkarımı için belirlenen ideal ölçek parametreler daha küçük iken yol detayının çıkarımı için belirlenen ideal ölçek parametresinin daha büyük olduğu gözlemlenmiştir. Bu sebepten dolayı şekil ve kompaktlık parametreleri sabit tutularak yapılan ölçek araştırmasında veri seti için uygun ölçek değeri bulunmuştur. Uygun görülen ölçek parametresinden daha büyük değerlerde, yol üzerindeki araba gibi nesnelerin yol ve zemin ile karıştığı gözlemlenmiştir. Daha küçük ölçek parametrelerinde ise küçük segmentlerin oluşmasından dolayı veri kalabalığı ortaya çıkmaktadır.

Yapılan denemelerde ölçek parametresi artırıldığında nesnelerin alanlarının da arttı̆̆ 1 görülmüştür. Şekil parametresi artırıldığında ise nesneler büyümektedir fakat bu büyüme ile nesnelerdeki homojenliğin azaldığı ve bir nesnenin içerisine birden fazla sınıfın dâhil olduğu görülmüştür ki bu da şekil parametresinin belirlenmesinde, nesnelerin spektral özelliklerinden çok nesnelerin boyut ve şekil özelliklerinden yararlanıldığını göstermektedir. Şekil parametresi 0,9 olarak alınan segmentasyon işleminde oluşan segmentlerde bina, yeşil alan, yol, taşıt ve toprak gibi sınıfların farklı kombinasyonlarda tek bir nesneye dâhil olduğu görülmüştür. Veri seti için segmentasyon parametreleri Tablo 2'de verilmiştir.

Tablo 2. Segmentasyon parametreleri

\begin{tabular}{lccccc}
\hline & Ölçek & Şekil & Renk & Yoğunluk & Yumuşaklık \\
\hline Değer & 150 & 0.1 & 0.9 & 0.5 & 0.5 \\
\hline
\end{tabular}

Veri setinde farklı parametre gruplarını, farklı özellik uzaylarını (farklı bantlar, indeksler veya kompozit bantlar), ölçek seviyelerini ve sınıflandırma kurallarını kullanarak farklı sınıf gruplarını veya bireysel sınıfları ayrı ayrı sınıflandırdık. Kullanılan kural setleri Tablo 1'de verilmiştir. Kural setleri ile bantların ortalamaları ve en yakın komşuluk algoritmaları kullanılarak oluşturulan sınıflandırılmış görüntüler Şekil 6'da verilmiştir.
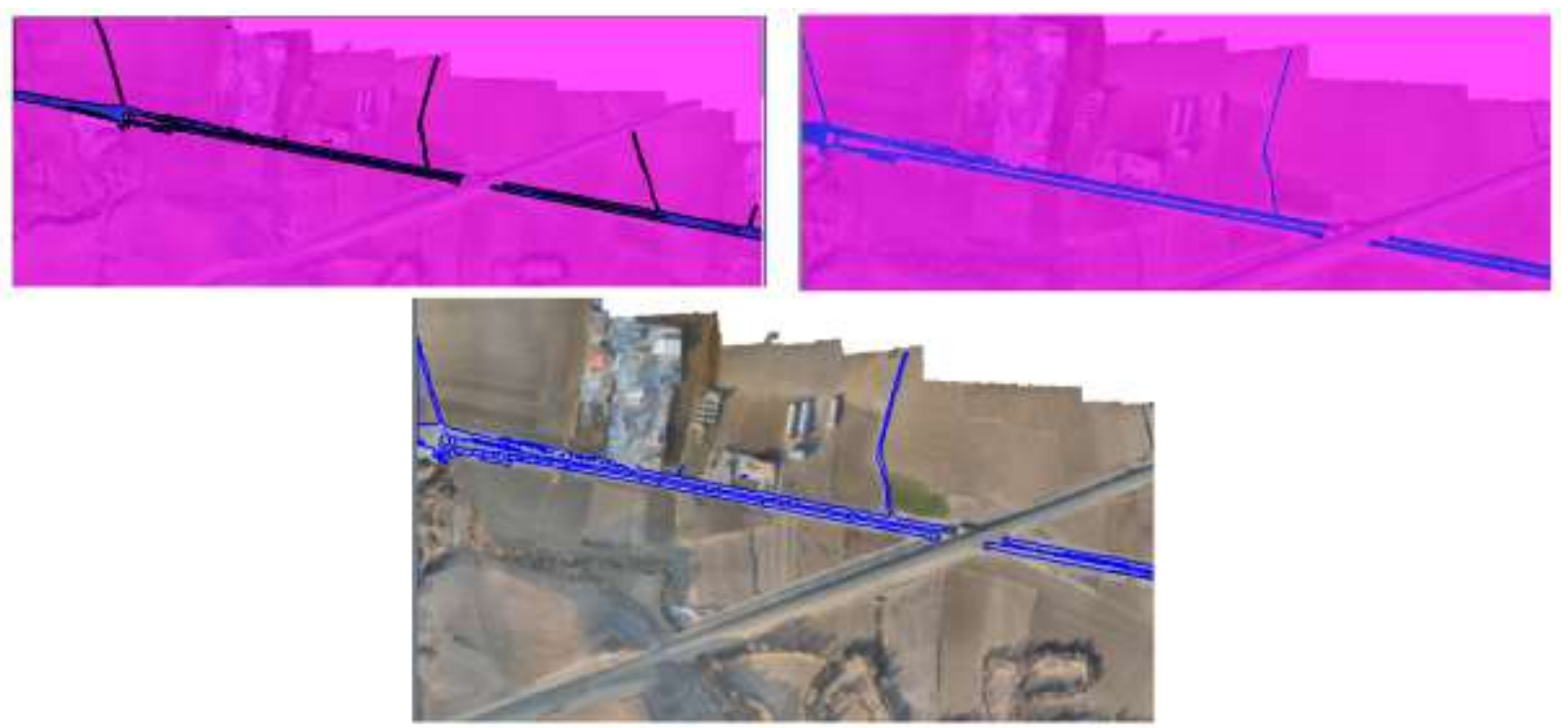

Şekil 6. Sınıflandırılmış görüntü

Sinıflandırma tamamlandıktan sonra mevcut sınıfların yer gerçeği ile ne kadar uyumlu olduğunu belirlemek için tüm çalışma alanında doğruluk analizi yapılmıştır. Doğruluk analizi, sınıflandırmanın doğruluğunu ve güvenilirliğini ölçmek için gerçekleştirilen son işlem adımıdır. Sınıflandırma sonuçlarının doğruluk analizi için ilk olarak eCognition yazılımın sağladığı "Test alanlarına dayalı hata matrisi (TTA/Training Test Area)” yaklaşımı kullanılmışır. Seçilen test alanlarının referans değerleri 
ile sınıflandırma sonucu karşılaştırılarak hata matrisi üretilmiş ve sınıflandırma kalitesi test edilmiştir. eCognition yazılımında doğruluk analizi sonrasında üretici ve kullanıcı doğruluğu ve Kapa istatistik değerleri hesaplanmıştır. Nesne tabanlı sınıflandırma metodu ile tespit edilen yolların doğruluk analizi ayrıca MapInfo yazılımında gerçekleştirilmiştir. Karşılaştırma verisi olarak daha önce klasik metotlarla üretilen vektör harita kullanılmış ve vektör harita referans kabul edilmiştir. Veri setine "rastgele nokta" yöntemi ile örneklem sayısı kadar noktalar atılmıştır. Rastgele üretilen noktalar ile tespit edilen yolların mekânsal doğrulukları incelenmiş ve bu amaçla; doğruluk, hassasiyet, duyarlılık, F1puanı ve özgünlük istatistiki değerleri hesaplanmıştır. Her iki yazılımda doğruluk değerleri Tablo 3 'te verilmiştir.

Tablo 3. Doğruluk analizi

\begin{tabular}{ccc}
\hline Yazılım & Doğruluk türü & Değer \\
\hline \multirow{3}{*}{ eCognition } & Üretici Doğruluğu & 0.771 \\
& Kullanıcı Doğruluğu & 0.860 \\
& Kapa & 0.795 \\
\hline \multirow{3}{*}{ MapInfo } & Doğruluk & 0.752 \\
& Hassasiyet & 0.815 \\
& Duyarlılık & 0.671 \\
& Flpuanı & 0.736 \\
& Özgünlük & 0.839 \\
\hline
\end{tabular}

Nesne tabanlı sınıflandırma yöntemi ile detay tespiti konulu benzer çalışmalar ve Tablo 3 incelendiğinde İHA' dan elde edilen yüksek çözünürlüklü görüntüler ile sınıflandırma sonuçları memnun edici seviyededir. Fakat İHA'dan elde edilen görüntüler ile yapılan sınıflandırmanın doğruluğunu iyileştirilmesini kısıtlayan ana faktör, sadece üç bant (kırmızı, yeşil ve mavi) ile zayıf spektral özellikleridir ve her bandın gri değeri yalnızca 0 ile 255 arasında olmasıdır.

Pande-Chhetri vd. (2017) çalışmalarında yüksek çözünürlüklü İHA görüntüleri ve nesne tabanlı sınfilandırma yöntemini kullanmışlardır. Çalışma sonucunda sınıflandırma doğruluğu nispeten düşük olmuştur ve en yüksek genel doğruluk yalnızca \%70.78 olarak bulunmuştur [43]. Tiwari vd., (2020) çalışmalarında nense tabanlı sınıflandırma yöntemi ile detay tespitinde çalışmadaki tüm sınıfların $\% 60$ ve üzeri doğrulukta olduğunu aktarmışlardır. Ayrıca çalışmada en yüksek doğruluk bina sınıflandırmasında yakalanırken yolların tespitinde $\% 90$ kullanıcı doğruluğu sağlanmıştır [46].

İHA RGB görüntüleri, zayıf spektral özelliklere sahip yüksek mekânsal çözünürlüğe sahiptir, İHA RGB görüntü spektral çözünürlügünün sınırlamalarını telafi etmek için RGB görüntülerine ek olarak yakın kızıl ötesi veya kırmızı kenar bant indekslerine sahip sensörler kullanılması sonuçların iyileştirilmesine katkı sağlayacağı düşünülmektedir.

\section{Sonuç ve Öneriler}

Son zamanlarda yüksek çözünürlüklü görüntüler üzerindeki spektral özellikleri ve bunların renk, doku ve şekil gibi objektif özelliklerini dikkate alan nesne tabanlı sınıflandırma tekniklerinin kullanılması görüntülerinin tematik sınıflandırılmasında daha yaygın hale gelmiştir. Nesneye dayalı sınıflandırma tekniği, görüntüleri segmentasyon aşamasında benzer spektral özellikler kullanarak kümeler oluşturması ve daha sonra segmentlere ayrilan görüntünün farklı sınıflara ait örnek nesnelerin seçimi ve son olarak sınıflandırma algoritmalarını kullanarak sınıflandırmanın tamamlanması işlemlerinden oluşmaktadır.

Segmentasyon, nesne yönelimli sınıflandırmada en önemli süreçtir. Nesneleri bölerek görüntünün bölümlere ayrılmasını sağlayan parametreler genellikle kullanıcı tarafindan belirlenmelidir. Ancak bu karar her çalışma alanı için özel olmalıdır. Segmentasyon sonucunda oluşturulan segmentler, sinıflandırma sonucunun doğruluğunu doğrudan etkiler. Segmentlerin yanlış oluşturulması da sinıflandırılan görüntüyü olumsuz etkilemektedir. Bu nedenle, bu sürecin bir sonucu olarak en ideal segmentler oluşturulmalıdır.

Nesne tabanlı sınıflandırma işleminin ikinci adımını segmentlerin sınıflara atanması işlemi oluşturmaktadır. Oluşturulan segmentleri sınıflara atamak için, görüntüleri literatürde kullanılan bant kombinasyonları ile gri renkli görüntülere dönüştürülmesi gerekmektedir. Bu işlemin amacı, 
görüntüdeki özellikler kullanılarak tespit edilmesi gereken sınıfın özelliklerini ortaya çıkarmaktır. Literatürde mevcut olan bant kombinasyonları, segmentasyon işlemi sonucunda ortofoto görüntüden elde edilen segmentleri sınıflara atamak için kullanılmıştır. Çeşitli bant kombinasyonları denendikten sonra birçok segmentin doğru sınıfa atandığı görülmüştür. Fakat yanlış sınıfa atanan segmentler sınıflandırmanın doğruluğunu düşürmektedir. Özellikle RGB bantların kullanıldığı çalışmalarda toprak sınıfı, yol sınıfı ile daha fazla karışmaktadır. Bunun temel nedeni olarak ortofoto görüntüsü sınıflandırmasında sadece üç bant kullanılması gösterilebilir. RGB bantlara ek olarak yakın kızılötesi ve kırmızı kenar bantların kullanılması ile sınıflandırmanın doğruluğunun artacağı düşünülmektedir.

Yapılan çalışma sonucunda, nesne tabanlı sınıflandırma metodu ile ana yollarda başarılı, tali yollarda orta derecede başarılı iken toprak yollarda başarısız olunmuştur. Yapılaşmanın az, yeşil alanların bol olduğu alanlarda yolların yüksek doğrulukta tespit edildiği görülmüştür. Yapılaşmanın düzgün ve fazla olduğu alanlarda düzensiz yapılaşmaya göre tali yolların tespitinin daha başarılı olunduğu görülmüştür. Ağaçların az olduğu alanlarda ana yollar, düzgün yapılaşmış kentsel alanlarda ise tali yollar nesne tabanlı yaklaşım ile etkili bir şekilde çıkarılabilmiştir. Yapılaşmanın seyrek, ağaçların ise yolları kapattığı alanlarda nesne tabanlı yaklaşımın başarısız olduğu tespit edilmiştir. Bunlara ek olarak toprak yollar ile ham arazi örtüsünün aynı spektral yansıma değerlerine sahip olması ve toprak yollar üzerinde bulunan otsu nesnelerin bulunması, toprak yolların nesne yönelimli bir yaklaşımla çıkarılmasında olumsuz etkiye sebep olduğu gözlemlenmiştir. Ortofoto görüntüdeki asfalt yol ile aynı spektral yansıma değerleri içeren özellikle beton çatılı binalar hem segmentasyonun kalitesini hem de sinıflandırmayı olumsuz etkilemektedir. Bu problemler uygun özellik ve farklı kurallar kullanılarak giderilmeye çalışılmıştır.

Uzun y1llardır kullanılan piksel tabanlı sınıflandırma yönteminin yerini alan nesne tabanlı sınıflandırma yönteminde segmentasyon işleminin yapılması, nesnelerin sınıflandırılmasında önemli bir etkiye sahiptir. Nesne tabanlı siniflandırma yazılımı olan Definiens eCognition ile yapılan sınıflandırma süreci daha hızlı ve güncellenebilir bir şekilde gerçekleşmektedir. Ayrıca yapılan yanlışlıklar ya da hatalı sınıf atamaları hızlı bir şekilde düzeltilebilir ve sınıflandırma sonucu vektör formata çevrilerek coğrafi bilgi sistemleri ile entegre edilebilir. Nesne tabanlı yöntemle yüksek çözünürlüklü görüntülerden elde edilen vektör veriler, harita üretim uygulamalarında kullanım amacına göre referans veri olarak kullanılabilir. Örneğin bu verileri; yasadışı, çarpık ve hızlı yapılaşmanın kontrolü için bir referans haritası olarak kullanmak mümkündür.

\section{Yazarların Katkısı}

Yazarlar bu araştırma makalesine eşit katkı sunmuşlardır.

\section{Çıkar Çatışması Beyanı}

Yazarlar arasında herhangi bir çıkar çatışması bulunmamaktadır.

\section{Araştırma ve Yayın Etiği Beyanı}

Yapılan çalışmada araştırma ve yayın etiğine uyulmuştur.

\section{Kaynaklar}

[1] Çelik C. 2007. AB ulaştırma politikasına uyum sürecinde Türkiye'de kara ulaşımı trafik güvenliği. Doktora tezi, Bahçe şehir Üniversitesi, Sosyal Bilimler Enstitüsü, İstanbul, 175.

[2] Ozan C. 2012. İyileştirilmiş pekiştirmeli öğrenme yöntemi ve dinamik yükleme ile kentiçi ulaşım ağlarının tasarımı, Doktora Tezi, Pamukkale Üniversitesi, Fen Bilimleri Enstitüsü, 186.

[3] Demirel A.Ş. 2010. Sayısal görüntü arşivi bilgi sistemi. Doktora tezi, Selçuk Üniversitesi, Fen Bilimleri Enstitüsü, 96.

[4] Kavzoglu T., Yildiz M. 2014. Parameter-based performance analysis of object-based image analysis using aerial and quikbird-2 images. ISPRS Annals of Photogrammetry, Remote Sensing and Spatial Information Sciences, II-7: 31-37. 
[5] Demir İ, 2012. Hadoop tabanlı büyük ölçekli görüntü işleme altyapısı. Yüksek Lisans Tezi, Kocaeli Üniversitesi, Fen Bilimleri Enstitüsü, 87.

[6] Polat N., Kaya Y. 2021. Çok Bantlı Uydu Görüntüleriyle Orman Yangınlarının Belirlenmesi ve Hasar Tespiti. Bartın Orman Fakültesi Dergisi, 23(1).

[7] Huang X., Zhang L. 2009. Road centreline extraction from high-resolution imagery based on multiscale structural features and support vector machines. International Journal of Remote Sensing, 30: 1977-1987.

[8] Polat N., Kaya Y. 2021. Investigation of the Performance of Different Pixel-Based Classification Methods in Land Use/Land Cover (LULC) Determination. Türkiye İnsansız Hava Araçları Dergisi, 3(1), 1-6.

[9] Bergsjö J. 2014. Object based change detection in urban area using KTH-SEG. Bachelor Thesis, Kth Royal Institute Of Technology, Stockholm.

[10] Gamba P., Dell'Acqua F., Lisini G. 2006. Improving urban road extraction in high-resolution images exploiting directional filtering, perceptual grouping, and simple topological concepts. IEEE Geoscience and Remote Sensing, 3: 387-391.

[11] Binaghi E., Gallo I., Pepe M. 2003. A cognitive pyramid for contextual classification of remote sensing images. IEEE Transactions on Geoscience and Remote Sensing, 41, 2906-2922.

[12] Long H., Zhao Z. 2005. Urban road extraction from high-resolution optical satellite images. International Journal of Remote Sensing, 26: 4907-4921.

[13] Zhu C., Shi W., Pesaresi M., Liu L., Chen X., King B. 2005. The recognition of road network from high-resolution satellite remotely sensed data using image morphological characteristics. International Journal of Remote Sensing, 26: 5493-5508.

[14] Polat, N., \& Uysal, M. (2020). An investigation of tree extraction from UAV-based photogrammetric dense point cloud. Arabian Journal of Geosciences, 13(17): 1-8.

[15] Bacher U., Mayer H. 2005. Automatic road extraction from multispectral high resolution satellite 1mages. IAPRS, 36, Vienna, Austria, August 29-30: 2005.

[16] Wang R. Hu Y., Zhang X. 2005. Extraction of road networks using pan-sharpened multispectral and panchromatic quickbird images. Geomatica, 59 (3): 1-28.

[17] Tapan K.S., Bölme M., Eker O. 2015. Görüntülerden sınıflandırma yöntemlerini kullanarak detayların otomatik olarak belirlenmesi: renkli kızılötesi hava fotoğraflarından ormanlık alanlarda yolların belirlenmesi için bir sınıflandırma uygulaması, TUFUAB VIII. Teknik Sempozyumu, Konya.

[18] Ural S., Shana J., Romeroa M.A., Tarkoa A. 2015. Road and roadside feature extraction using imagery and lidar data for transportation operation. ISPRS Annals of the Photogrammetry, Remote Sensing and Spatial Information Sciences, II-3/W4: 239-246.

[19] Becker C., H“ani N., Rosinskaya E., d'Angelo E., Strecha C. 2017. Classification of aerial photogrammetric 3D point clouds. arXiv:1705.08374v1.

[20] Sabuncu A., Sunar F. 2017. Ortofotolar ile nesne tabanlı görüntü sınıflandırma uygulaması: Vanerciş depremi örneği. Artvin Çoruh Üniversitesi Doğal Afetler Uygulama ve Araştırma Merkezi Doğal Afetler ve Çevre Dergisi, 1: 1-8.

[21] Widyaningrum E., Lindenbergh R.C. 2019. Skeleton-based automatic road network extraction from an orthophoto colored point cloud. The 40th Asian onference on Remote Sensing (ACRS 2019), Daejeon, Korea.

[22] Geng R., Jin S., Fu B., Wang B. 2021. Object-Based Wetland Classification Using Multi-Feature Combination of Ultra-High Spatial Resolution Multispectral Images. Canadian Journal of Remote Sensing, 1-27.

[23] Zeybek M. 2021. Classification of UAV point clouds by random forest machine learning algorithm. Turkish Journal of Engineering, 5(2): 48-57

[24] Marangoz A.M. 2009. Uydu görüntülerinden kentsel ayrıntıların nesne-tabanlı sınıflandırma yöntemiyle belirlenmesi ve CBS ortamında bütünleştirilmesi, Doktora tezi, Yıldız Teknik Üniversitesi, Fen Bilimleri Enstitüsü, İstanbul, 133.

[25] Bilgilioğlu B.B. 2015. Uzaktan algılanmış görüntülerden faydalınalarak nesne tabanlı sınıflandırma yöntemi ile kent merkezlerindeki detayların çıkarımı ve yorumlanması. Yüksek Lisans Tezi, Aksaray Üniversitesi, Fen Bilimleri Enstitüsü, Aksaray, 79. 
[26] Kaya Y., Polat N. 2020. Investigation Of Phenological Stages of Wheat Plant Using Vegetation Index. Mersin Photogrammetry Journal, 2(1): 24-28.

[27] Hoffman R., Jain A.K. 1987. Segmentation and classification of range images. IEEE Transactions on Pattern Analysis and Machine Intelligence, 9: 608-620.

[28] Kaya Y., Polat N. 2021. Bitki İndeksleri Kullanarak Buğday Bitkisinin Rekolte Tahmini. Dicle Üniversitesi Mühendislik Fakültesi Mühendislik Dergisi, 12(1): 99-110.

[29] Baatz M., Schäpe A. 1999. Object-oriented and multiscale image analysis in semantic networks. In: Proc. Of the 2nd International Symposium on Operalization of Remote Sensing, August 16th20th, Enschede. ITC.

[30] Çömert R., Matcı D.K., Avdan U. 2017. Yıkılmış Binaların Nesne Tabanlı Sınıflandırma ile İnsansız Hava Aracı Verilerinden Tespit Edilmesi, 4. Uluslararası Deprem Mühendisliği ve Sismoloji Konferans1, Eskişehir.

[31] Woebbecke D.M., Meyer G.E., Von B.K., Mortensen D.A. 1995. Color indices for weed identification under various soil, residue, and lighting conditions. Trans. ASAE 38: 259-269.

[32] Sonnentag O., Hufkens K., Teshera-Sterne C., Young A.M., Friedl M., Braswell B. H., et al. 2012. Digital repeat photography for phenological research in forest ecosystems. Agricultural and Forest Meteorology, 152: 159-177.

[33] Motohka T., Nasahara K.N., Oguma H., Tsuchida S. 2010. Applicability of green-red vegetation index for remote sensing of vegetation phenology. Remote Sensing, 2: 2369-2387.

[34] Gitelson A.Y., Kaufman Y.J., Merzylak M. 1996. Use of a green channel in remote sensing of global vegetation from eos-modis. Remote Sensing of Environment, 58: 289-298.

[35] Mao W., Wang Y., Wang Y. 2003. Real-time detection of between-row weeds using machine vision, In 2003 ASAE Annual Meeting (p. 1). American Society of Agricultural and Biological Engineers.

[36] Lu D., Mausel P., Brondi'zio E., Moran E. 2004. Change detection techniques. INT. J. Remote Sensing, 25 (12): 2365-2407.

[37] Yiğit A.Y., Uysal M. 2020. Automatic road detection from orthophoto images. Mersin Photogrammetry Journal, 2 (1): 10-17.

[38] Çölkesen İ., Sesli F.A. 2007. Kıyı çizgisinde meydana gelen zamansal değişimlerin bilgi teknolojileri ile belirlenmesi: Trabzon örneği. TMMOB Harita ve Kadastro Mühendisleri Odas1 Ulusal Coğrafi Bilgi Sistemleri Kongresi, KTÜ, Trabzon.

[39] Musaoğlu N. 1999. Elektro-optik ve aktif mikrodalga algilayıc1lardan elde edilen uydu verilerinden orman alanlarında meşcere tiplerinin ve yetişme ortamı birimlerinin belirlenme olanakları, Doktora Tezi, İstanbul Teknik Üniversitesi, Fen Bilimleri Enstitüsü, 127.

[40] Muñoz N., Bosch F.X., De Sanjosé S., Herrero R., Castellsagué X., Shah K.V., Meijer C.J. 2003. Epidemiologic classification of human papillomavirus types associated with cervical cancer. New England journal of medicine, 348 (6): 518-527.

[41] Belgiu M., Draagut L. 2016. Random forest in remote sensing: A review of applications and future directions. ISPRS Journal of Photogrammetry and Remote Sensing, 114: 24-31.

[42] Tian Y., Jia M., Wang Z., Mao D., Du B., Wang C. 2020. Monitoring invasion process of Spartina alterniflora by seasonal Sentinel-2 imagery and an object-based random forest classification. Remote Sensing, 12 (9): 1383.

[43] Pande-Chhetri R., Abd-Elrahman A., Liu T., Morton J., Wilhelm V.L. 2017. Object-based classification of wetland vegetation using very high-resolution unmanned air system imagery. European Journal of Remote Sensing, 50(1): 564-576.

[44] Definiens. 2008. Definiens Developer 7.0. User Guide, Munich, Germany.

[45] Definiens. 2012. Definiens Developer XD 2.0.4. Reference Book, Definiens AG München, Germany.

[46] Tiwari A., Sharma S.K., Dixit A., Mishra V. 2020. UAV Remote Sensing for Campus Monitoring: A Comparative Evaluation of Nearest Neighbor and Rule-Based Classification. Journal of the Indian Society of Remote Sensing, 1-13. 